\title{
Estimation of Above Ground Biomass and carbon stocks of Tectona grandis and Gmelina arborea stands in Gorontalo Province, Indonesia
}

\author{
YOSEP RUSLIM ${ }^{1, \boldsymbol{}}$, DAUD SANDALAYUK ${ }^{2}$, ROCHADI KRISTININGRUM ${ }^{1}$, ANDI SAHRI ALAM $^{3}$ \\ ${ }^{1}$ Faculty of Forestry, Universitas Mulawarman. Jl. Ki Hajar Dewantara, Kampus Gunung Kelua, Samarinda Ulu, Samarinda 75123, East Kalimantan, \\ Indonesia. Tel./fax.: +62-541-735379, `email: yruslim@gmail.com \\ ${ }^{2}$ Faculty of Forestry, Universitas Negeri Gorontalo. J1. Jend. Sudirman No. 247, Limboto, Gorontalo 96211, Gorontalo, Indonesia \\ ${ }^{3}$ Faculty of Forestry, Universitas Tadulako. Jl. Soekarno Hatta Km 9, Kampus Bumi Tadulako, Tondo, Palu 94148. Central Sulawesi, Indonesia
}

Manuscript received: 17 January 2021. Revision accepted: 25 February 2021

\begin{abstract}
Ruslim Y, Sandalayuk D, Kristiningrum R, Alam AS. 2021. Estimation of Above Ground Biomass and carbon stocks of Tectona grandis and Gmelina arborea stand in Gorontalo Province, Indonesia. Biodiversitas 22: 1497-1508. Plantation forest plays an important role to fulfill timber needs, while more recently plantation forest is increasingly acknowledged to sequester and store carbon which can mitigate climate change and also as carbon sequestration for the environment. This study aimed to calculate the stand potential, stand biomass and carbon stocks of teak (Tectona grandis) and gmelina (Gmelina arborea) stands in the context of land after being abandoned in Gorontalo Province, Indonesia. Four plots with size of one hectare each were sampled in which each species (i.e. teak and gmelina) consisted of two plots. In each plot, the diameter at the breast-high $(1.3 \mathrm{~m})$ and the height of each individual were recorded. Data analysis included growth parameters of the stands (i.e., Mean Annual Increment/MAI and Current Annual Increment/CAI) and above-ground biomass and carbon sequestered by the stands. Simple linear regression using polynomial trendline was used to determine the relationship between variables and the degree of the relationship. The results showed that the maximum growth of teak stands at Plots I and II reached a maximum point at the age of 32 and 25 years with the total volume of 307.50 and $254.81 \mathrm{~m}^{3} \mathrm{ha}^{-1}$, respectively. While the maximum growth of gmelina stands at Plots I and II reached a maximum point at the age of 15 years with the total volume of 190.54 and $251.80 \mathrm{~m}^{3} \mathrm{ha}^{-1}$, respectively. The biomass content in teak stands at Plots I and II and gmelina stands at Plots I and II were respectively 267.83; 221.94; 104.03 and 137.48 tons ha ${ }^{-1}$. Meanwhile, the carbon content in teak stands at Plots I and II and gmelina stands at Plots I and II were respectively 125.88; 104.31; 48.90; and 64.62 tons ha ${ }^{-1}$. The results of the regression analysis suggest that there was strong relationship between carbon sequestered and the age of the stands as well as total basal area. The results of this study suggest that Tectona grandis is more potential to be developed as plantation forest than Gmelina arborea when aiming at carbon sequestration and biomass production.
\end{abstract}

Keywords: Biomass, carbon, Gmelina arborea, growth, Tectona grandis

\section{INTRODUCTION}

There is a growing paradigm that forest management is not only aimed to produce timber and non-timber products, but also to deliver various ecosystem services. One of forest ecosystem services is the sequestration of carbon dioxide in the atmosphere through photosynthesis and to store it in forest biomass (Lukito and Rohmatiah 2013). The carbon stored in forest biomass can help mitigate climate change in the form of global warming (Birdsey and Pan 2015; Calfapietra et al. 2015; Zeng et al. 2018; Pandey et al. 2019).

Tesfaye et al. (2016) stated that tropical forests play an important role in global carbon sequestration. Among ecosystems in the world, forests in tropical regions have the highest rate of carbon sequestration due to a large amount of sunlight and water in the regions which is plentiful throughout the year. These conditions are also supported by the climates (i.e., temperature and humidity) that optimal for many tree species to grow. Most of carbon sequestered by the forest is stored in above-ground biomass of the trees.
Indonesia has renewable natural resources such as plantation forests. Plantation forestry has the potential to be developed as biomass storage by promoting the planting of fast-growing plants. When developing plantation forests, the estimation of biomass in tree stands is very important to calculate the amount and variation of C (Ekholm 2016; Gren and Zeleke 2016; Riutta et al. 2018; Nonini and Fiala 2019). Biomass is also important to determine forest production to assess the sustainability aspect of forest management (Rinnamang et al. 2020) since the existence of plantations requires sustainability in terms of financial, ecological, and social aspects (Siregar et al. 2017). If achieved across such aspects, sustainable management of plantation forest would result in high production of wood products while could store a large amount of carbon (Wei and Zhou 2019; Cuong et al. 2020). In addition to producing wood and biomass, sustainably managed forest plantations would also provide environmental services in the form of water regulation (Chauhan et al. 2016b; Nemeth et al. 2018). 
According to Gonzalez-Benecke et al. (2015), Sharma et al. (2016), Panwar et al. (2017), the length of rotation of plantation forests will affect the biomass and carbon stored by the forest. The rotation length is related to the type of tree species planted, either it is fast-growing or slowgrowing species. The ability of fast-growing trees to absorb carbon which is faster than slow-growing species is one of the strong reasons why it is necessary to plant and cultivate fast-growing species in plantation forests (Chauhan et al. 2016a)

One type of fast-growing tree species is Gmelina (Gmelina arborea Roxb). This tree is widely developed for industrial plantations in tropical regions, such as Indonesia, Pakistan, Sri Lanka, and some countries in Southeast Asia. Gmelina can live well in lowland areas up to an altitude of $1200 \mathrm{~m}$ above sea level with an average rainfall of 750$5000 \mathrm{~mm}$ year $^{-1}$ (Adinugraha and Setiadi 2018). Another tree species that is widely cultivated is teak (Tectona grandis Linn.f.). Teak is an important commercial timber tree that has a high selling price (Warner et al. 2017) due to the timber is relatively light with high durability and resistant to fire as well as easy to work on (Meunpong 2012).

One important parameter when estimating the biomass of tree stands is allometric equation. Yet, in several regions and particular contexts of land management, the allometric equation is not adequately formulated (Karyati et al. 2019). This study aimed to calculate the stand potential, stand biomass and carbon stocks of Teak and Gmelina stands in the context of land after being abandoned in Gorontalo, Indonesia. We expected that this research can develop allometric equation for estimating AGB with a coefficient of determination that can predict biomass and carbon stock in such land management.

\section{MATERIALS AND METHODS}

\section{Study period and area}

The study was conducted from September 2020 to December 2020 in Gorontalo Province, Indonesia. The field experiments were conducted at four plots, consisting of two plots of Tectona grandis and two plots of Gmelina arborea. (i) Location A was gmelina plot II, in Dulupi Village, Boalemo District (122'36'12.888' 'E, $\left.0^{\circ} 37^{\prime} 47.828^{\prime} \mathrm{N}\right)$. (ii) Location B was teak plot I, in Bakti Village, Boalemo District (12242'22.942'E; $\left.0^{\circ} 37^{\prime} 43.117^{\prime} \mathrm{N}\right)$. (iii) Location C was gmelina plot I, in Bakti Village, Boalemo District (122\%43'51.600' $\mathrm{E}$, $\left.0^{\circ} 37^{\prime} 55.966^{\prime} \mathrm{N}\right)$. (iv) Location D was teak plot II, in HayaHaya Village, Gorontalo District (122'49'15.397' $\mathrm{E}$, $0^{\circ} 38^{\prime} 46.017^{\prime} \mathrm{N}$ ) (Figure 1).

\section{Data collection procedure}

The determination of the study locations (Figure 1). Each plot of tree stand had the extent of 1 hectare with different planting distances. The planting distance of Tectona grandis stand was $3 \mathrm{~m} \times 3 \mathrm{~m}$, while that of Gmelina arborea was $3.5 \mathrm{~m} \times 4 \mathrm{~m}$. In each plot, the diameter at the breast-high $(1.3 \mathrm{~m})$ and the height of each individual were recorded. Data collection related to diameter and height was carried out from 2 until 15 year. Measurements were carried out twice a year. While those over 15 years of age are simulated mathematically using simple linear regression to find the closeness of the regression coefficient relationship between age and increment. This study is also based on research conducted by Sist et al. (2003), that the formation of arithmetic simulation models and logical operations on the yield cycle and sustainable harvesting in lowland dipterocarp mixed forest on the island of East Kalimantan can be estimated using simple linear regression.

\section{Data analysis \\ Estimating the growth (MAI and CAI)}

The data collection includes diameter, plant species as high as $1.3 \mathrm{~m}$ from the soil surface $(\mathrm{cm})$. Carbon (C) storage ( $\mathrm{kg}$ per year) can be estimated by multiplying the tree biomass (Y: $\mathrm{kg}$ ) with the general vegetation carbon content, namely (0.46) (Hairiah and Rahayu 2007). Carbon stock calculations were also carried out on cultivated plants Tectona grandis (teak) and Gmelina arborea (white teak) planted on land by the community.

The maximum production of the stand of $T$. grandis and $G$. arborea was analyzed by calculating the growth increments of trees in a particular measurement time span (cycle), namely mean annual increment (MAI) and current annual increment (CAI). Van Gardingen et al. (2003) state that increment is defined as an increase in the dimensional growth (height, diameter, base plane, volume) or an increase in the standing stock of a tree, in relation to the tree age or a particular period. The volume of the tree was calculated using following equation:

$$
\mathrm{V}=\frac{1}{4} \pi \mathrm{d}^{2} \mathrm{hf}
$$

Where: V: standing volume, d: diameter at breast height $(\mathrm{DBH}), \mathrm{h}$ : branch-free height, f: form factor

According to Van Gardingen et al. (2003), to estimate the mean annual increment (MAI) and the current annual increment, the following formulas were used:

$$
\mathrm{MAI}=\frac{\mathrm{V}_{\mathrm{t}}}{\mathrm{t}}
$$

Where: MAI: mean annual increment, $\mathrm{V}_{\mathrm{t}}$ : total volume in ages $\mathrm{t}_{0}-\mathrm{t}\left(\mathrm{m}^{3}\right), \mathrm{t}$ : age (years)

$$
\mathrm{CAI}=\frac{\mathrm{V}_{\mathrm{t}}-\mathrm{V}_{\mathrm{t}-1}}{\mathrm{~T}}
$$

Where: CAI: current annual increment, $\mathrm{V}_{\mathrm{t}}=$ total volume in ages $\mathrm{t}_{0}-\mathrm{t}\left(\mathrm{m}^{3}\right), \mathrm{V}_{\mathrm{t}-1}$ : previous total volume $\left(\mathrm{m}^{3}\right)$, $\mathrm{T}$ : second age $\mathrm{t}_{0}-\mathrm{t}$, minus the first age (in year) 

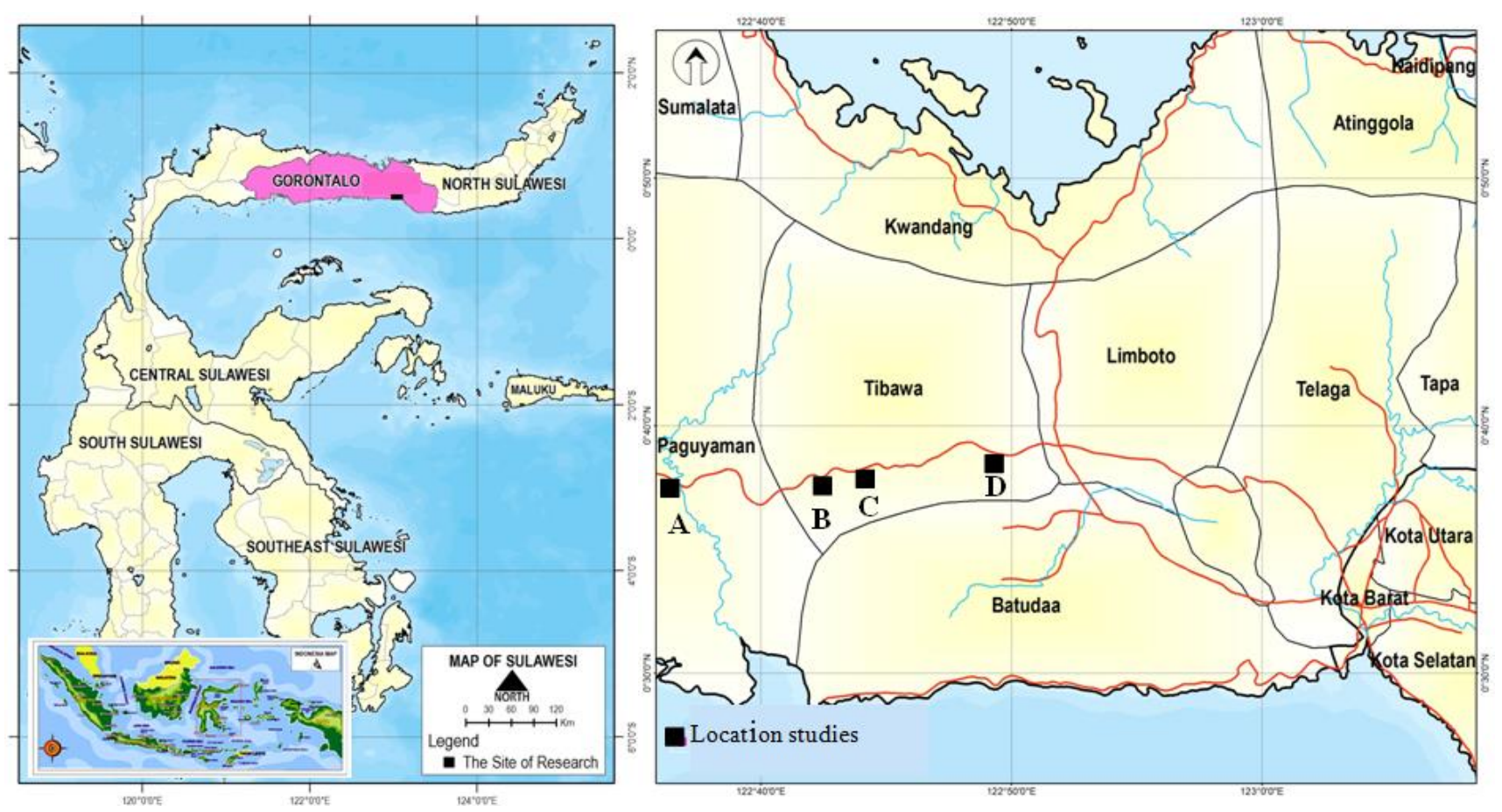

Figure 1. Map of study sites in Gorontalo Province, Indonesia. Note: A. Gmelina arborea plot II, B. Tectona grandis plot I, C. G. arborea plot I, D. T. grandis plot II

\section{Estimating tree biomass and carbon}

Tree biomass can be estimated by incorporating tree height, trunk diameter, and wood density (Chave et al. 2014). The biomass was calculated according to Indonesian National Standard [SNI] number 7724 (2011) and Irundu et al. (2020) using the following formula:

$$
\mathrm{M}=\mathrm{BJ} \times \mathrm{V}_{\mathrm{t}} \times \mathrm{BEF}
$$

Where: M: tree biomass $(\mathrm{kg}), \mathrm{BJ}$ : specific gravity $(\mathrm{kg}$ $\left.\mathrm{m}^{-3}\right), \mathrm{V}_{\mathrm{t}}$ : total volume $\left(\mathrm{m}^{3}\right)$, BEF: Biomass Expansion Factor (1.3)

While carbon storage was calculated as follow:

$$
\mathrm{Cb}=\mathrm{B} \times \% \mathrm{C} \text { Organic }
$$

Where: $\mathrm{Cb}$ : Carbon content of biomass $(\mathrm{kg}), \mathrm{B}$ : total biomass $(\mathrm{kg}), \% \mathrm{C}$ Organic: Percentage value of carbon content, which is 0.47 (Hairiah et al. 2011).

The total biomass was calculated by multiplying the biomass obtained per plot with the conversion unit to ton $\mathrm{ha}^{-1}$. According to Adhitya et al. (2013), the calculation of the biomass content per hectares was as follow:

Biomass $\left(\mathrm{kg} \mathrm{ha}^{-1}\right)=$ Biomass $\left(\mathrm{kg} \mathrm{m}^{-2}\right) \times 10,000 \mathrm{~m}^{2}$

Biomass and stored carbon have a causal relationship with tree volume values. Therefore, the data obtained was analyzed mathematically using simple linear regression to find relationship between age and increment, while polynomial trendline was used to determine the regression coefficient. Determination of the value of biomass and stored carbon can be determined through a volume value approach. According to Ruslianto et al. (2019), the relationships between biomass and tree dimensions can be analyzed as follows:

$\hat{\mathrm{Y}}=\mathrm{a}+\mathrm{bX}$

Where: $\hat{Y}=$ Estimated value of biomass, $X=$ Volume $\left(\mathrm{m}^{3}\right), \mathrm{a}, \mathrm{b}=$ regression constant

\section{RESULTS AND DISCUSSION}

\section{Growth of Tectona grandis}

Growth of Tectona grandis at Plot I

T. grandis stands cultivated at Plot I at the beginning were planted at a spacing of $3 \mathrm{~m} \times 3 \mathrm{~m}$, resulted in the initial number of 1,111 individuals. As the stands grew, it experienced a reduction in the number of trees due to natural mortality or thinning activity. The number of trees, diameter, height, total volume, and increment of teak are presented in Table 1.

Based on the table above, it can be explained that at a one-hectare of plot I there were 910 individuals at the age of 2 years trees with an average diameter of $3.1 \mathrm{~cm}$, height of 2 meters and total volume of $1.10 \mathrm{~m}^{3} \mathrm{ha}^{-1}$. At the age of 35 years, the number of individuals were reduced to 400 with average diameter of $45 \mathrm{~cm}$, height of 8.7 meters, and total volume of $331.91 \mathrm{~m}^{3} \mathrm{ha}^{-1}$. Meanwhile, the mean annual increment of volume ranged from 0.55 to 9.61 $\mathrm{m}^{3} \mathrm{ha}^{-1}$ year $^{-1}$. The maximum total volume of teak reached at the age of 32 years with $307.50 \mathrm{~m}^{3} \mathrm{ha}^{-1}$ with mean annual increment (MAI) of 9.61 and current annual increment (CAI) of $9.86 \mathrm{~m}^{3} \mathrm{ha}^{-1} \mathrm{year}^{-1}$ with the number of individuals of 500 trees per hectare. 
The graphical presentation of MAI and CAI of teak in plot $\mathrm{I}$ is presented in Figure 2. Based on Figure 2, it can be explained that the MAI and CAI increments of teak initially increased and met at one point, namely at the age of 32 years. This means that the maximum increment of teak is reached at the age of 32 years. After experiencing maximum increment at the age of 32 years, the teak will experience a decline after such age. This is supported by a simple linear regression test with a polynomial type on MAI which has an $\mathrm{R}^{2}$ value of $99 \%$. This value means that there is a close relationship between age and the MAI increment of $99 \%$ and $1 \%$ influenced by other factors. Meanwhile, CAI has an $\mathrm{R}^{2}$ value of $97 \%$. This value means that there is a close relationship between age and the CAI increment of $97 \%$ and $3 \%$ is influenced by other factors.

\section{Growth of Tectona grandis at Plot II}

Similar to Plot I, as many as 1,111 individuals of $T$. grandis were cultivated at plot II at the beginning, but these were reduced to 400 individuals at the age of 30 years. However, at a later age, the teak stands experienced a reduction in the number of trees due to natural mortality or due to thinning activities. The table of growth of $T$. grandis at Plot II is presented in Table 2. The results in Table 2 showed that at Plot II there were 800 individuals of teak at the age of 2 years with average diameter of $3 \mathrm{~cm}$, height of 2 meters and total volume of $0.90 \mathrm{~m}^{3} \mathrm{ha}^{-1}$. At the age of 30 years, the number of individuals was reduced to 400 trees with average diameter of $38 \mathrm{~cm}$, height of 9.3 meters and total volume of $229.28 \mathrm{~m}^{3} \mathrm{ha}^{-1}$. The growth increment ranged from 0.45 to $9.17 \mathrm{~m}^{3} \mathrm{ha}^{-1}$ year $^{-1}$ with the maximum total volume of teak reached at the age of 25 years with $229.28 \mathrm{~m}^{3} \mathrm{ha}^{-1}$ and MAI dan CAI of 9.17 and $9.78 \mathrm{~m}^{3} \mathrm{ha}^{-}$ ${ }^{1}$ year $^{-1}$, respectively with the number of trees per hectare as many as 500 trees.

The graphical presentation of MAI and CAI of teak at Plot II can be seen in Figure 3. Based on Figure 3, it can be explained that the MAI and CAI increments initially increased and met at one point, namely the age of 32 years. This means that the maximum increment of teak was reached at the age of 25 years and then declined after such age. After experiencing a maximum increment at the age of 25 years, the teak after the age of 25 years will experience a decline. The curves also suggest that there is a close relationship between age and MAI and CAI in which both parameters have high This is supported by a simple linear regression test with a polynomial type on MAI which has an $\mathrm{R}^{2}$ value of $95 \%$ and. This value means that there is a close relationship between age and MAI increment of $95 \%$ and $5 \%$ influenced by other factors. Meanwhile, CAI has an $\mathrm{R}^{2}$ value of $88 \%$, respectively. This value means that there is a close relationship between age and the CAI increment of $86 \%$ and $14 \%$ is influenced by other factors.

Table 1. The table growth of T. grandis in Plot I

\begin{tabular}{lccccccccrr}
\hline Age & n & d & h & f & TV & MAI & CAI & BA & \multicolumn{1}{c}{ Biomass } & Carbon \\
\hline 2 & 910 & 3.1 & 2 & 0.8 & 1.10 & 0.55 & & 0.69 & 0.96 & 0.45 \\
4 & 880 & 5.9 & 3.5 & 0.8 & 6.73 & 1.68 & 2.82 & 2.40 & 5.86 & 2.76 \\
7 & 750 & 8.8 & 5.3 & 0.8 & 9.33 & 2.76 & 4.20 & 4.56 & 16.84 & 7.91 \\
9 & 700 & 10.9 & 6.3 & 0.8 & 2.90 & 3.66 & 6.79 & 6.53 & 28.66 & 13.47 \\
10 & 610 & 12.4 & 6.9 & 0.8 & 40.88 & 4.09 & 7.97 & 7.36 & 35.60 & 16.73 \\
15 & 600 & 20.0 & 7.5 & 0.7 & 98.91 & 6.59 & 11.61 & 18.84 & 86.15 & 40.49 \\
20 & 570 & 26.0 & 7.8 & 0.7 & 165.79 & 8.29 & 13.38 & 30.25 & 144.40 & 67.87 \\
25 & 560 & 31.0 & 7.8 & 0.7 & 230.66 & 9.23 & 12.97 & 42.25 & 200.91 & 94.43 \\
30 & 550 & 37.5 & 7.9 & 0.6 & 287.79 & 9.59 & 11.43 & 60.71 & 250.66 & 117.81 \\
32 & 500 & 40.4 & 8.0 & 0.6 & 307.50 & 9.61 & 9.86 & 64.06 & 267.83 & 125.88 \\
34 & 460 & 42.0 & 8.5 & 0.6 & 324.86 & 9.55 & 8.68 & 63.70 & 282.95 & 132.99 \\
35 & 400 & 45.0 & 8.7 & 0.6 & 331.91 & 9.48 & 7.05 & 63.59 & 289.10 & 135.88 \\
\hline
\end{tabular}

Note: $\mathrm{N}$ : number of individuals of $T$. grandis $\left(\right.$ tree ha $\left.{ }^{-1}\right)$, d: tree diameter $(\mathrm{cm})$, h: clear bole height $(\mathrm{m}), \mathrm{F}$ : form factor, TV: total volume $\left(\mathrm{m}^{3}\right.$ ha ${ }^{-}$

$\left.{ }^{1}\right)$, MAI: Mean Annual Increment $\left(\mathrm{m}^{3} \mathrm{ha}^{-1}\right.$ year $\left.{ }^{-1}\right)$, CAI: Current Annual Increment $\left(\mathrm{m}^{3} \mathrm{ha}^{-1}\right.$ year $\left.{ }^{-1}\right)$, BA: Basal Area $\left(\mathrm{m}^{2} \mathrm{ha}\right)$

Table 2. The table growth of T. grandis in Plot II

\begin{tabular}{lccccccccrr}
\hline Age & n & \multicolumn{1}{c}{ D } & h & f & \multicolumn{1}{c}{ TV } & MAI & CAI & \multicolumn{1}{l}{ BA } & Biomass & Carbon \\
\hline 2 & 800 & 3.0 & 2.0 & 0.80 & 0.90 & 0.45 & & 0.57 & 0.79 & 0.37 \\
4 & 700 & 6.0 & 3.7 & 0.77 & 5.64 & 1.41 & 2.37 & 1.98 & 2.91 & 2.31 \\
7 & 650 & 9.0 & 4.7 & 0.75 & 14.57 & 2.08 & 2.98 & 4.13 & 12.69 & 5.96 \\
8 & 630 & 10.0 & 5.3 & 0.74 & 19.40 & 2.42 & 4.83 & 4.95 & 16.89 & 7.94 \\
9 & 604 & 12.0 & 5.8 & 0.73 & 28.91 & 3.21 & 9.51 & 6.83 & 25.18 & 11.83 \\
10 & 580 & 14.0 & 6.1 & 0.72 & 38.87 & 3.89 & 9.96 & 8.92 & 33.86 & 15.91 \\
15 & 560 & 21.5 & 7.7 & 0.72 & 112.66 & 7.51 & 14.76 & 20.32 & 98.12 & 46.12 \\
20 & 550 & 26.5 & 8.5 & 0.70 & 180.40 & 9.02 & 13.55 & 30.32 & 157.13 & 73.85 \\
$\mathbf{2 5}$ & $\mathbf{5 0 0}$ & $\mathbf{3 1 . 6}$ & $\mathbf{9 . 0}$ & $\mathbf{0 . 6 5}$ & $\mathbf{2 2 9 . 2 8}$ & $\mathbf{9 . 1 7}$ & $\mathbf{9 . 7 8}$ & $\mathbf{3 9 . 1 9}$ & $\mathbf{1 9 9 . 7 0}$ & $\mathbf{9 3 . 8 6}$ \\
30 & 400 & 38.0 & 9.3 & 0.60 & 253.82 & 8.46 & 4.91 & 45.34 & 221.08 & 103.91 \\
\hline
\end{tabular}

Note: N: number of individuals of T. grandis $\left(\right.$ tree ha $\left.^{-1}\right)$, d: tree diameter $(\mathrm{cm})$, h: clear bole height $(\mathrm{m}), \mathrm{F}$ : form factor, TV: total volume $\left(\mathrm{m}^{3}\right.$ ha ${ }^{-}$

$\left.{ }^{1}\right)$, MAI: Mean Annual Increment $\left(\mathrm{m}^{3} \mathrm{ha}^{-1}\right.$ year $\left.^{-1}\right)$, CAI: Current Annual Increment $\left(\mathrm{m}^{3} \mathrm{ha}^{-1}\right.$ year $\left.{ }^{-1}\right)$, BA: Basal Area $\left(\mathrm{m}^{2} h a\right)$ 


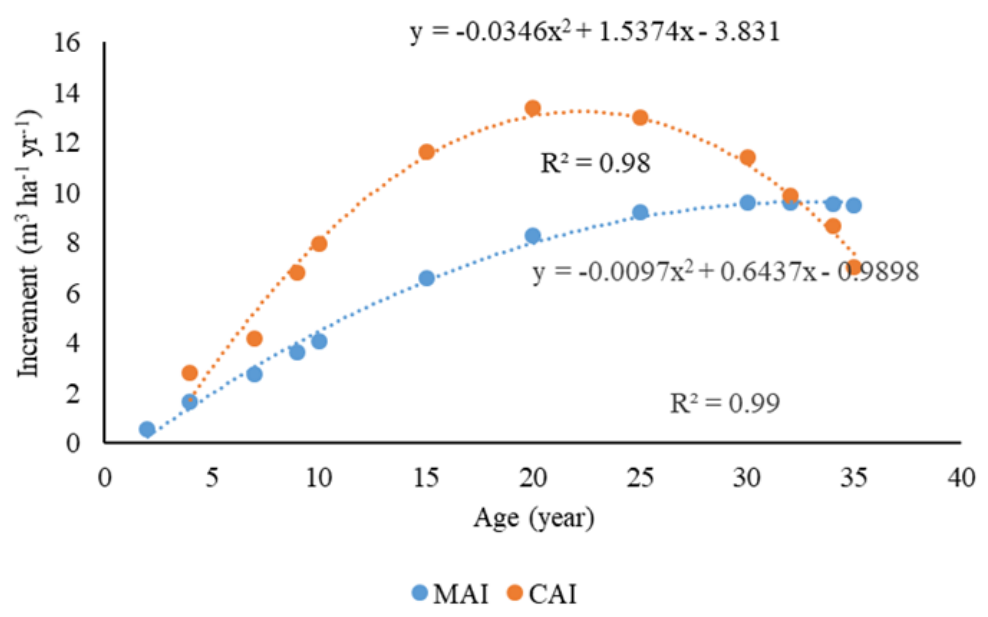

Figure 2. The curves of MAI and CAI of T. grandis at Plot I

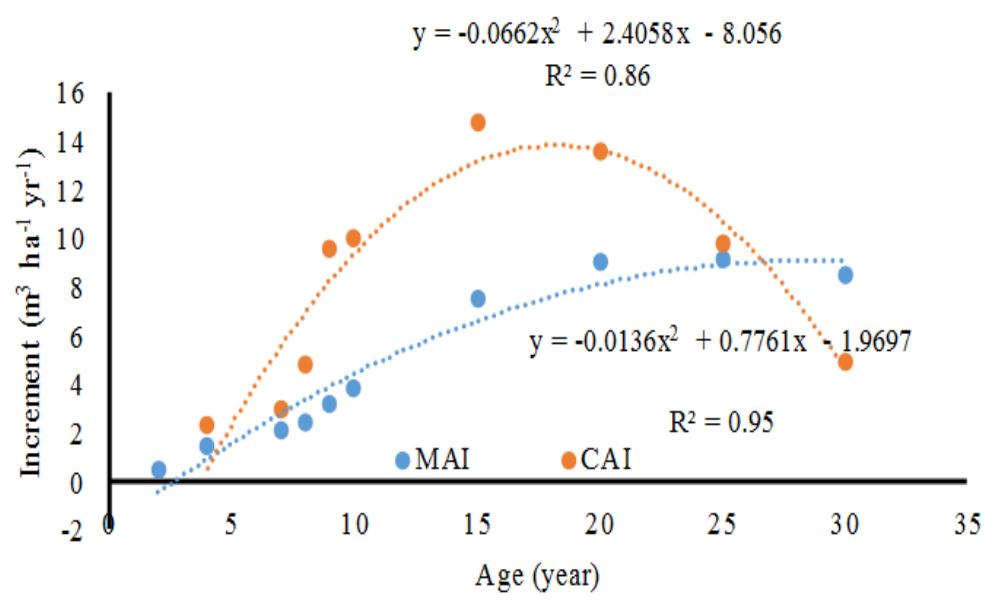

Figure 3. The curves of MAI and CAI of T. grandis at Plot II

The growth pattern as shown in Figures and 3 suggests that teak growth at a young age is to be more developed. Sousa et al. (2011) stated that the growth of teak stands in East Timor generally shows a decline in growth along with the increasing age of the stands. The growth of a tree stand, both in height and diameter, is influenced by climate and soil fertility. In addition, it is also influenced by the space and surface of the canopy, relative humidity and the root system (Juwari et al. 2020a).

The highest growth in diameter and height of the teak stands occurred in the early stages of growth, namely in the range of 1-5 years of age, then there was a gradual decline in growth and was seen to decrease after 12 years of age stands. Until the stand was 12 years old, generally teak growth in East Kalimantan showed a higher growth (increment) in diameter and height compared to several teak plant locations in Java. Alam et al. (2017), Setiawan et al. (2011) and Setiawan et al. (2019) who conducted research in Samboja District, East Kalimantan Province, stated that the potential of total volume and increment of
"Super" teak at the age of 25 were $154.32 \mathrm{~m}^{3}$ and 6.17 $\mathrm{m}^{3} \mathrm{ha}^{-1}$ year $^{-1}$, respectively while those in Solomon teak were $150.94 \mathrm{~m}^{3}$ and $6.04 \mathrm{~m}^{3} \mathrm{ha}^{-1}$ year $^{-1}$, respectively.

Another study in Nganjuk, East Java stated that the diameter increment of teak cultivated from root graft reached $25-28 \mathrm{~cm}$ at the age of 20 years, while the diameter increment of the original plant is only $1-2 \mathrm{~cm} \mathrm{year}^{-1}$. In optimal site conditions, teak volume increment can reach 7.9 - $10 \mathrm{~m}^{3} \mathrm{ha}^{-1}$ year $^{-1}$ (Susila 2012). Yunianti et al. (2011) stated that in terms of silviculture, plants with long rotation were modified to accelerate their growth in order to meet market demand. The wide spacing will produce trees with big appearance, and in terms of quantity is very profitable, while in terms of wood quality, plants modified to accelerate their growth will reduce their wood properties, especially the strength. As such, the effort taken should be to choose a place to grow that is very suitable for the plant so that even though its growth is accelerated, the quality of the wood remains stable. 


\section{Growth of Gmelina arborea}

Growth of Gmelina arborea at Plot I

Gmelina arborea cultivated at Plot I at the beginning were planted at a distance of $3.5 \mathrm{~m} \times 4 \mathrm{~m}$, resulted in the initial number of 714 individuals. Similar to teak, Gmelina stands experienced a reduction in the number of trees due to natural mortality or thinning activity. The number of trees, diameter, height, total volume and increment of Gmelina at Plot I are presented in Table 3. However, at a later age, the G. arborea stands experienced a reduction in the number of trees due to natural mortality or due to thinning activities. Based on the G. arborea growth table, the number of trees, diameter, height, total volume and increment of G. arborea can be seen in Table 3.

Based on Table 3, there were 660 individuals of Gmelina with average diameter of $6 \mathrm{~cm}$ at the age of 2 years. At the age 25 years, the diameter increased to $34 \mathrm{~cm}$, while the height increased from 4 to 14 meters and the total volume enhanced from 6.71 to $284.58 \mathrm{~m}^{3} \mathrm{ha}^{-1}$. The MAI ranged from 3.36 to $12.70 \mathrm{~m}^{3} \mathrm{ha}^{-1}$ year $^{-1}$. The maximum total volume of $G$. arborea reached at the age of 15 years with $190.54 \mathrm{~m}^{3} \mathrm{ha}^{-1}$ and MAI and CAI of 12.70 and 13.28 $\mathrm{m}^{3} \mathrm{ha}^{-1}$ year $^{-1}$, respectively, with the number of trees per hectare, were 430 trees. The curves of MAI and CAI of $G$. arborea at Plot I are presented in Figure 4.

Figure 4 suggests that the MAI and CAI of G. arborea initially increased reached and met at one point, namely the age of 15 years. This means reached the maximum increment at the age of 15 years and then declined after such age. After experiencing a maximum increment at the age of 15 years, the G. arborea after the age of 15 years will experience a decline. The simple linear regression test with a polynomial type on MAI shows an $\mathrm{R}^{2}$ value of $90 \%$, meaning that there is a close relationship between age and the MAI increment of $91 \%$ and $9 \%$ was influenced by other factors. Meanwhile, CAI has an $\mathrm{R}^{2}$ value of $98 \%$, implying that there is a close relationship between age and the CAI increment of $98 \%$ and $2 \%$ was influenced by other factors.

\section{Growth of Gmelina arborea at Plot II}

The number of trees, diameter, height, total volume and increment of Gmelina at Plot II are presented in Table 4. The results in Table 4 show that at Plot II, there were 660 G. arborea trees per hectare at the age of 2 years with average diameter of $5 \mathrm{~cm}$. At the age of 25 years, the diameter increased to $35.5 \mathrm{~cm}$, while the height increased from 3 to 15 meters and the total volume increased from 3.50 to $351.40 \mathrm{~m}^{3} \mathrm{ha}^{-1}$. The MAI ranged from 1.75 to 16.69 $\mathrm{m}^{3} \mathrm{ha}^{-1} \mathrm{year}^{-1}$. The maximum total volume of $G$. arborea reached at the age of 15 years with $251.80 \mathrm{~m}^{3} \mathrm{ha}^{-1}$ and MAI and CAI of 16.79 and $16.69 \mathrm{~m}^{3} \mathrm{ha}^{-1} \mathrm{year}^{-1}$, respectively with the number of trees per hectare was 450 .

The graphical relationship between MAI and CAI $G$. arborea in plot II can be seen in Figure 5. Similar to Gmelina stand at Plot I, the maximum increment of Gmelina at Plot II was reached at the age of 15 years, in which the increment declined after such age. After experiencing a maximum increment at the age of 15 years, the $G$. arborea after the age of 15 years will experience a decline. The influence of age is significant as the results of simple linear regression test with a polynomial type on MAI and CAI have an $\mathrm{R}^{2}$ value of $86 \%$ and $98 \%$, respectively.

Figures 6 and 7 show stand of T. grandis and G. arborea at 15 years from plots I and II.

Table 3. The table growth of Gmelina arborea at Plot I

\begin{tabular}{lllllllllll}
\hline Age & n & D & h & f & TV & MAI & CAI & BA & Biomass & Carbon \\
\hline 2 & 660 & 6 & 4 & 0.90 & 6.71 & 3.36 & & 1.87 & 3.67 & 1.72 \\
4 & 570 & 13 & 5 & 0.87 & 32.89 & 8.22 & 13.09 & 7.56 & 17.96 & 8.44 \\
6 & 550 & 17 & 5.5 & 0.88 & 60.39 & 10.07 & 13.75 & 12.48 & 32.97 & 15.50 \\
8 & 530 & 21 & 6 & 0.82 & 90.27 & 11.28 & 14.94 & 18.35 & 49.29 & 23.17 \\
10 & 500 & 23.6 & 7 & 0.79 & 120.89 & 12.09 & 15.31 & 21.86 & 66.01 & 31.02 \\
12 & 470 & 24.6 & 9 & 0.75 & 150.71 & 12.56 & 14.91 & 22.33 & 82.29 & 38.68 \\
15 & 430 & 28 & 10 & 0.72 & 190.54 & 12.70 & 13.28 & 26.46 & 104.03 & 48.90 \\
20 & 360 & 32 & 12 & 0.71 & 248.29 & 12.41 & 11.55 & 28.94 & 135.57 & 63.72 \\
25 & 350 & 34 & 14 & 0.64 & 284.58 & 11.38 & 7.26 & 31.76 & 155.38 & 73.03 \\
\hline
\end{tabular}

Notes: N: number of individuals of G. arborea $\left(\right.$ tree ha $\left.^{-1}\right)$, d: tree diameter $(\mathrm{cm})$, h: clear bole height (m), F: form factor, TV: total volume $\left(\mathrm{m}^{3} \mathrm{ha}^{-1}\right)$, MAI: Mean Annual Increment $\left(\mathrm{m}^{3} \mathrm{ha}^{-1}\right.$ year $\left.{ }^{-1}\right)$, CAI: Current Annual Increment $\left(\mathrm{m}^{3} \mathrm{ha}^{-1}\right.$ year $\left.{ }^{-1}\right)$, BA: Basal Area $\left(\mathrm{m}^{2} \mathrm{ha}\right)$

Table 4. The table growth of Gmelina arborea at Plot II

\begin{tabular}{|c|c|c|c|c|c|c|c|c|c|c|}
\hline Age & $\mathbf{n}$ & d & $\mathbf{h}$ & $\mathbf{F}$ & TV & MAI & CAI & BA & Biomass & Carbon \\
\hline 2 & 660 & 5 & 3 & 0.90 & 3.50 & 1.75 & & 1.30 & 1.91 & 0.90 \\
\hline 4 & 600 & 13.8 & 5.3 & 0.87 & 41.36 & 10.34 & 18.93 & 8.97 & 22.58 & 10.61 \\
\hline 6 & 570 & 18.5 & 6.2 & 0.86 & 81.65 & 13.61 & 20.15 & 15.31 & 44.58 & 20.95 \\
\hline 8 & 540 & 21.3 & 8 & 0.80 & 123.08 & 15.39 & 20.72 & 19.23 & 67.20 & 31.59 \\
\hline 10 & 510 & 23.5 & 9.5 & 0.78 & 163.83 & 16.38 & 20.37 & 22.11 & 89.45 & 42.04 \\
\hline 12 & 470 & 27 & 10 & 0.75 & 201.72 & 16.81 & 18.95 & 26.90 & 110.14 & 51.77 \\
\hline 15 & 450 & 30 & 11 & 0.72 & 251.80 & 16.79 & 16.69 & 31.79 & 137.48 & 64.62 \\
\hline 20 & 380 & 34 & 13 & 0.70 & 313.80 & 15.69 & 12.40 & 34.48 & 171.33 & 80.53 \\
\hline 25 & 370 & 35.5 & 15 & 0.64 & 351.40 & 14.06 & 7.52 & 36.60 & 191.86 & 90.18 \\
\hline
\end{tabular}

Notes: N: number of individuals of G. arborea $\left(\right.$ tree ha $\left.^{-1}\right)$, d: tree diameter $(\mathrm{cm})$, h: clear bole height (m), F: form factor, TV: total volume $\left(\mathrm{m}^{3} \mathrm{ha}^{-1}\right)$, MAI: Mean Annual Increment $\left(\mathrm{m}^{3} \mathrm{ha}^{-1}\right.$ year $\left.{ }^{-1}\right)$, CAI: Current Annual Increment $\left(\mathrm{m}^{3} \mathrm{ha}^{-1}\right.$ year $\left.{ }^{-1}\right)$, BA: Basal Area $\left(\mathrm{m}^{2} \mathrm{ha}\right)$ 
Table 5. The total volume, basal area, biomass and carbon of each stand

\begin{tabular}{lccccc}
\hline Type & $\begin{array}{c}\text { Age } \\
(\mathbf{y r})\end{array}$ & $\begin{array}{c}\text { TV } \\
\left(\mathbf{m}^{\mathbf{3}} \mathbf{h a}\right.\end{array}$ & $\begin{array}{c}\mathbf{- 1}) \\
\left(\mathbf{m}^{\mathbf{2}} \mathbf{h a}\right.\end{array}$ & $\begin{array}{c}\text { Biomass } \\
\left(\mathbf{t o n} \mathbf{h a}^{\mathbf{- 1}}\right)\end{array}$ & $\begin{array}{c}\text { Carbon } \\
\left(\mathbf{t o n} \mathbf{h a}^{\mathbf{- 1}}\right)\end{array}$ \\
\hline T. grandis Plot I & 32 & 307.50 & 64.06 & 267.83 & 125.88 \\
T. grandis Plot II & 25 & 254.81 & 43.56 & 221.94 & 104.31 \\
G. arborea Plot I & 15 & 190.54 & 26.46 & 104.03 & 48.90 \\
G. arborea Plot II & 15 & 251.80 & 31.79 & 137.48 & 64.62 \\
\hline
\end{tabular}

Notes: TV: Total volume $\left(\mathrm{m}^{3} \mathrm{ha}^{-1}\right)$, BA: Basal area $\left(\mathrm{m}^{2} \mathrm{ha}^{-1}\right)$

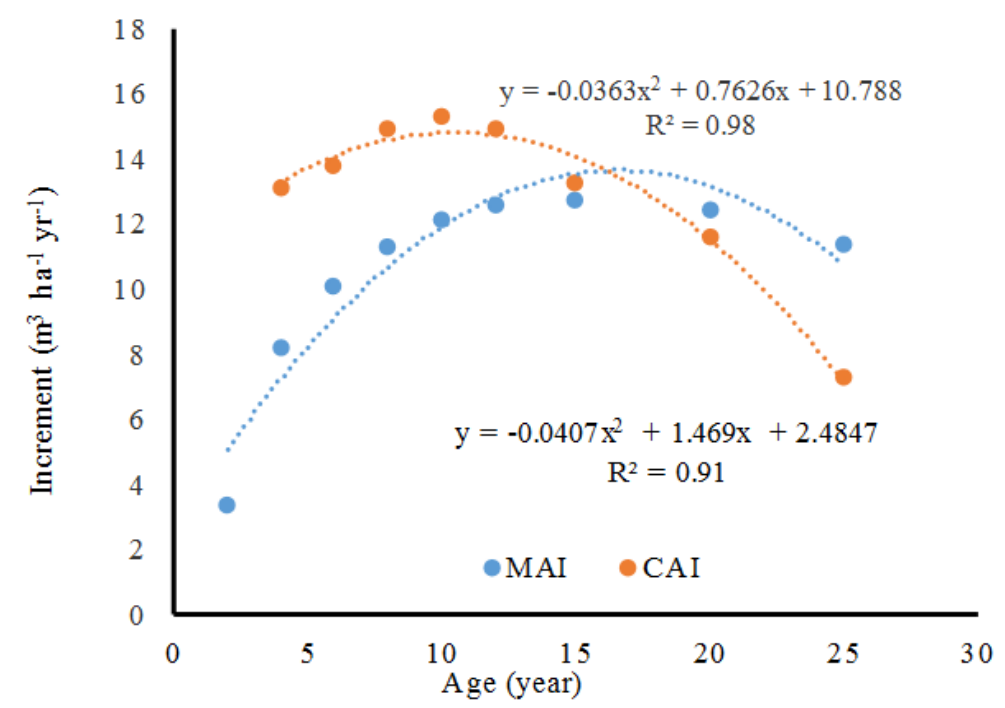

Figure 4. The curves of MAI and CAI of Gmelina arborea at Plot I

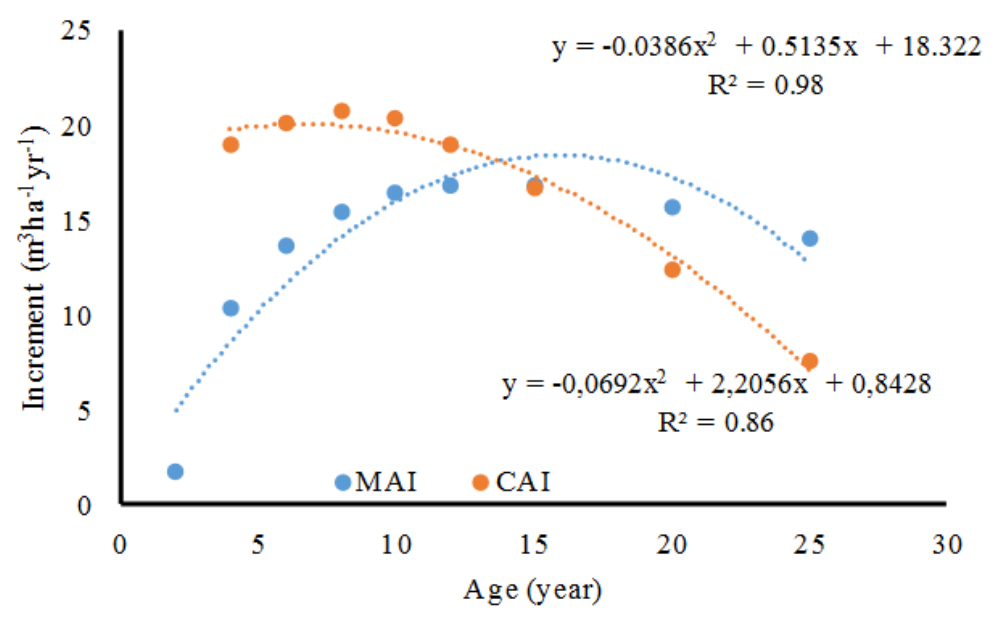

Figure 5. The curves of MAI and CAI of Gmelina arborea at Plot II

According to Sandalayuk et al. (2018) and Sandalayuk et al. (2020), the increase in diameter reached $2.4 \mathrm{~cm}_{\text {year }}{ }^{-1}$ at the age of 10 , and resembles an increase in diameter of Jabon of $2.1 \mathrm{~cm}^{\text {year }}{ }^{-1}$. Meanwhile, according to our result, the increase in Gmelina diameter at the age of 10 was 2.36 $\mathrm{cm}$ year $^{-1}$. The maximum total volume of $G$. arborea was achieved at the age of 15 years of biological rotation with total volume of $190.54 \mathrm{~m}^{3} \mathrm{ha}^{-1}$ and MAI and CAI of 12.70 and $13.28 \mathrm{~m}^{3} \mathrm{ha}^{-1}$ year ${ }^{-1}$, respectively with the number of trees is 430. According to Siarudin and Indrayana (2015), if
Gmelina arborea is harvested at the age of 14 years, it has a total volume of $122 \mathrm{~m}^{3} \mathrm{ha}^{-1}$ and average diameter of 15 $\mathrm{cm}$, whereas if harvested at the age of 20 years, the diameter is $20 \mathrm{~cm}$ and the total volume is $146 \mathrm{~m}^{3} \mathrm{ha}^{-1}$. This means that the age of a stand also influences the biomass and the amount of carbon stored in a stand (Lukito and Rohmatiah 2013). This means that the age of a stand also influences the biomass and the amount of carbon stored in a stand (Lukito and Rohmatiah 2013). 
The graphs presented in Figures 2, 3, 4 and 5 are in line with Kristiningrum et al. (2019), Winarni et al. (2017) and Dinga (2014) in which the growth of $T$. grandis and $G$. arborea exhibited certain characteristics, as follow: CAI curve rapidly reached the peak and from there declined immediately, whereas the MAI curve climbed and declined slowly. However, the potential growth of teak stands was better than that of gmelina stands. This is likely due to differences in spacing and density per hectare. One of the factors that can affect the size of the stand diameter is the density and intensity of sunlight entering the stand. According to Sedjarawan et al. (2014), stand density will affect the light entering the vegetation. Stands that receive little sunlight will experience slow growth so that they have a small stem diameter. In addition, the light intensity will also have an influence on cell enlargement and differentiation such as height growth, leaf size and the structure of the leaves and stems.
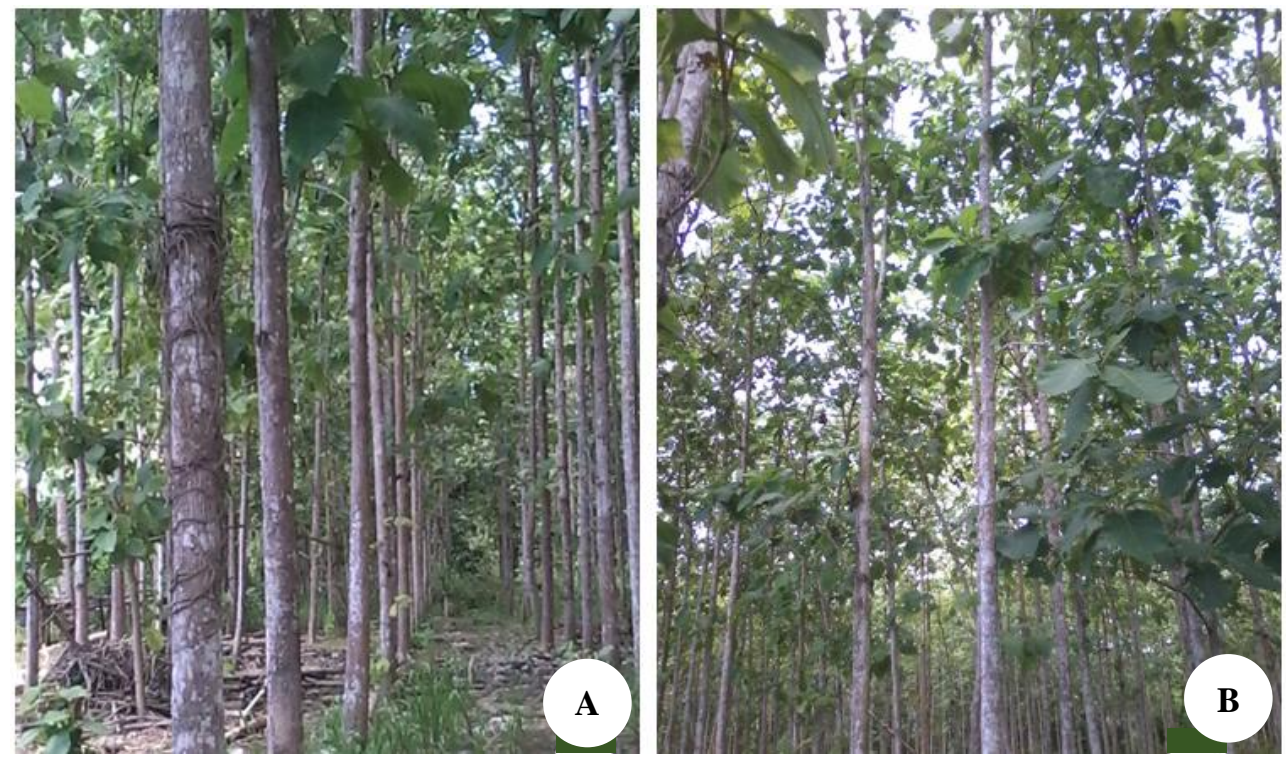

Figure 6. Stands of Tectona grandis at the age of 15 years with spacing of $3 \mathrm{~m} \times 3 \mathrm{~m}$ : A. Stands at Plot I; B. Stands at Plot II
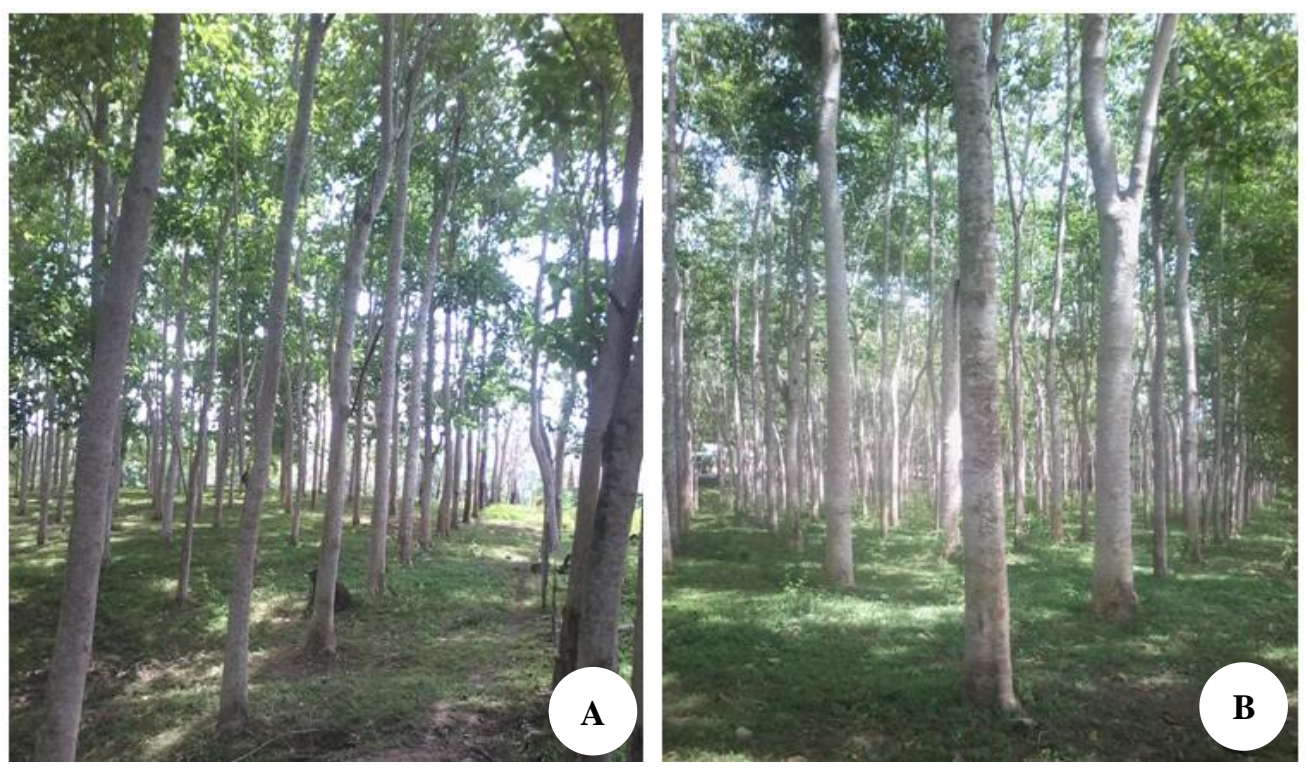

Figure 7. Stands of Gmelina arborea at the age of 15 years with spacing of $3.5 \mathrm{~m} \times 4 \mathrm{~m}$ : A. stands at Plot I; B. stands at Plot II. 


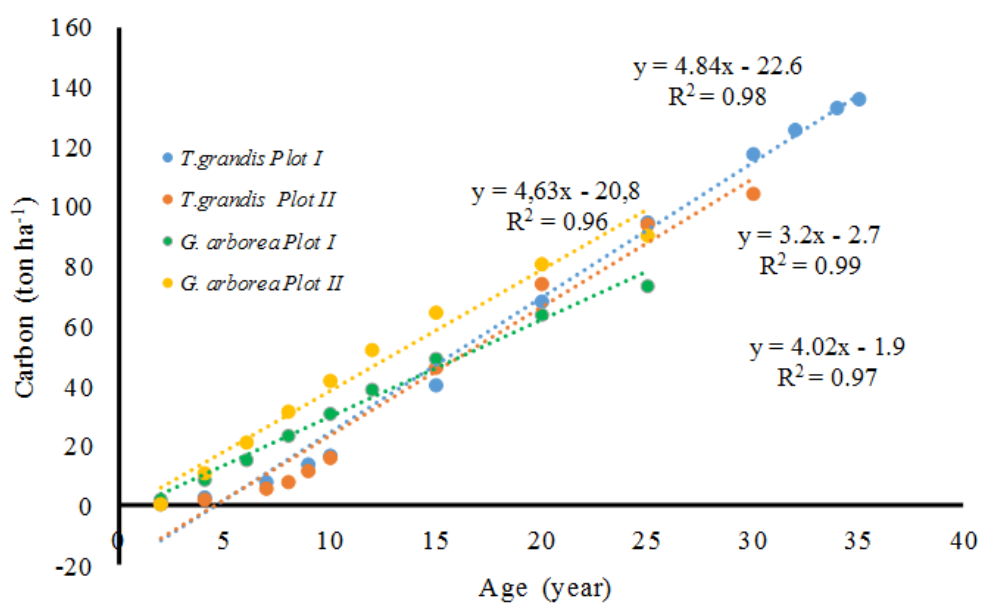

Figure 8. The correlation between the stand age and carbon sequestered at the stands of Tectona grandis and Gmelina arborea

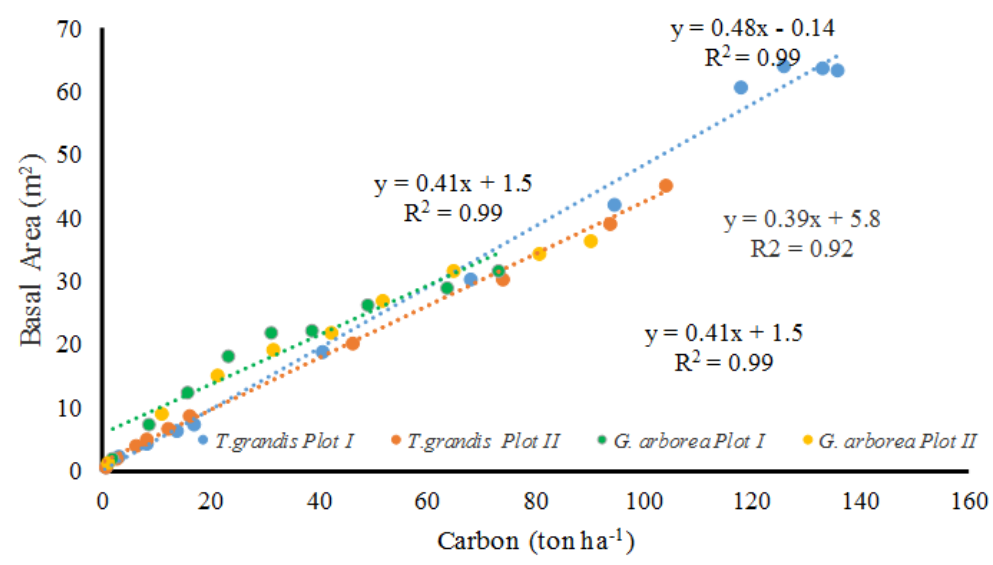

Figure 9. The correlation between basal area and carbon sequestered at the stands of Tectona grandis and Gmelina arborea

\section{Tree biomass and carbon sequestered}

The calculations of the total volume, basal area, biomass and carbon are presented in Table 5. This table demonstrates that the teak stand at Plot I with the age of 32 years had the largest total volume, basal area, biomass and carbon among other stands of $307.5 \mathrm{~m}^{3} \mathrm{ha}^{-1}$; $64.06 \mathrm{~m}^{2} \mathrm{ha}^{-1}$; 257.83 ton $\mathrm{ha}^{-1}$ and 125.88 ton $\mathrm{ha}^{-1}$, respectively, then followed by teak Plot II, gmelina Plot II and finally gmelina Plot I. These differences are due to the different fertility level in each type of stand. The teak at Plot 2 at the age of 25 years had a total volume of $254.81 \mathrm{~m}^{3} \mathrm{ha}^{-1}$, basal area $43.56 \mathrm{~m}^{2} \mathrm{ha}^{-1}$; biomass 221.94 ton $\mathrm{ha}^{-1}$ and carbon 104.31 ton $\mathrm{ha}^{-1}$. G. arborea at Plot II at the age of 15 years had a total volume of $251.80 \mathrm{~m}^{3} \mathrm{ha}^{-1}$, basal area $31.79 \mathrm{~m}^{2}$ $\mathrm{ha}^{-1}$; biomass 137.48 ton ha $\mathrm{ha}^{-1}$ and carbon 64.62 ton $\mathrm{ha}^{-1}$, while G. arborea at Plot 1 at the age of 15 years had a total volume $190.54 \mathrm{~m}^{3} \mathrm{ha}^{-1}$, basal area $26.46 \mathrm{~m}^{2} \mathrm{ha}^{-1}$; biomass 104.03 ton $\mathrm{ha}^{-1}$ and carbon 48.90 ton $\mathrm{ha}^{-1}$.

The amount of carbon in gmelina Plot I is almost the same as the amount of Gmelina arborea in East Kutai District, East Kalimantan, Indonesia (Amirta et al. 2016). Trimanto (2014) stated that $G$. arborea tends to store carbon smaller with 19.96 ton $\mathrm{C} \mathrm{ha}^{-1}$ or 2.49 ton $\mathrm{C} \mathrm{ha}^{-1} \mathrm{yr}^{-1}$ compared to $T$. grandis which can store carbon of 114.88 ton $\mathrm{C} \mathrm{ha}^{-1}$ or 9.57 ton $\mathrm{C} \mathrm{ha}^{-1} \mathrm{yr}^{-1}$. Our results show that both younger stands of teak and gmelina produce higher tree densities when compared with older stands. However, the basal area of older stands is larger than that of younger stands. This is in line with research conducted by Rinnamang et al. (2020). In addition, the management of stands has a significant effect on the characteristics of the stands and the soil content as a place to grow stands. Therefore, good forest managers must apply intensive forest management practices optimize the benefits of plantations (Kumi et al. 2020).

The relationship between stand age and carbon sequestered in each type of stand is presented in Figure 8. Meanwhile, the relationship between basal area and carbon sequestered in each type of stand is presented in Figure 9. Based on Figures 8 and 9, carbon sequestered has strong relationships with age and basal area, which is indicated by high correlation value $\left(\mathrm{R}^{2}\right)$. This result is in line with the research conducted by Kumi et al. (2020) in which teak biomass estimation was very accurate and ignored differences in areas, tree characteristics and diameters that had high, constant ratios, stems and sharp crowns with 
determination coefficient $\left(\mathrm{R}^{2}=0.99\right)$ and significant (Bredu and Birigazzi 2014).

The increase in $\mathrm{CO}_{2}$ gas emissions in the air causes an increase in global temperatures on earth. Information regarding the amount of carbon absorbed in the plant biomass (carbon stock) in an area becomes very important information (Trimanto 2014). On the other hand, $\mathrm{CO}_{2}$ is an important component in the photosynthesis process and the carbon dioxide absorbed by forest stands compose carbohydrates as a result of photosynthesis which will be stored in the form of biomass. Therefore, the amount of above-ground biomass can be used as a basis for determining the amount of carbon stock or the amount of $\mathrm{CO}_{2}$ absorbed and stored by the stands (Uthbah et al. 2017). According to Sardjono et al. (2017), biomass has a very strong relationship with photosynthesis process. Biomass increases because plants absorb $\mathrm{CO}_{2}$ from the air and convert it into organic compounds through the process of photosynthesis.

Putri and Wulandari (2015) stated that the biomass of a stand can be estimated using an allometric equation whose parameter is the diameter of the stand. The large diameter of the stands causes the greater the biomass and carbon stored, and vice versa, the smaller the stand diameter, the smaller the biomass and carbon stored in it. The tree allometric equation can yield some estimates on standing volume, biomass and carbon stock. The equation obtained is a statistical model used to explain the relationship between the various components of a tree stand. It allows foresters to take simple measurements of tree stands, such as measuring diameter, height, biomass and carbon (Kasim et al. 2014).

Tuheteru and Husna (2011) explain that age is very influential in the sequestration of carbon. If the trees are getting older, their ability to absorb carbon is also high. Measurement of forest biomass in this research was conducted on the whole tree, consisted of aboveground biomass of stems, branches, and leaves. In addition, it turns out that the number of trees per hectare and the density of the stands greatly affect the presence of biomass and carbon. This means that the denser and healthier the stand, the greater the amount of biomass and carbon (Juwari et al. $2020 \mathrm{~b}$ ). This is in line with research conducted by Krisnawati et al. (2011) that there is a close relationship between age and carbon in A. cadamba. While Polosakan et al. (2014) and Uthbah et al. (2011) stated that the difference in the amount of biomass above the soil surface is influenced by the age of the stands. Stand age has an effect on biomass because stand age affects the volume of stems and density of stand wood. The older the stand, the higher the volume and density of wood stand.

The results of this study show that $T$. grandis stands had higher total stored carbon compared to G. arborea. The ability of $T$. grandis trees to absorb carbon dioxide $\left(\mathrm{CO}_{2}\right)$ makes this plant the most stored carbon among tree species. According to Lubis et al. (2013), the increase in biomass and carbon stored by trees goes hand in hand with the increase in the dimensions of the stem includes the diameter and height. Forest plantations play a critical role in mitigating the various effects of environmental degradation and increasing absorption of carbon dioxide in the atmosphere and also its consequences on climate change. Tree promotes sequestration of carbon into soil and plant biomass. The outcome of this study revealed that $T$ grandis and G. arborea have a great potential in promoting carbon sequestration especially when they are allowed to grow older. Favorable growth conditions have high potential of increasing the biomass accumulation of this species. Hence, it is recommended that sustainable management of this plantation should be paramount in securing a cleaner environment and mitigating the effect of climate change in Indonesia.

\section{ACKNOWLEDGEMENTS}

We would like to express our gratitude to Umbar Sujoko and Muhammad Rafii Nur Fauzan for their help in creating the map of the study site. The authors would like to acknowledge Karyati, Rita Diana, and anonymous reviewers for providing constructive comments to improve the manuscript.

\section{REFERENCES}

Adhitya PW, Hardiansyah G, Yani A. 2013. Estimation of surface carbon content on a tree in the Ketapang Regency City forest area. J Sustain For 2 (1): 23-32.

Adinugraha HA, Setiadi D. 2018. Selection of seed trees of Gmelina arborea Roxb. at smallholder forest in Bondowoso, East Java. Tropical Forest J 16 (1): 6-12. DOI: 10.20527/jht.v6i1.5099

Alam AS, Rafiuddin, Setiawan, B. 2017. Financial analysis systems teak and elephant grass agroforestry in Samboja District Kutai Kartanegara Regency, East Kalimantan. Proceedings National Biodiversity Conservation, Univ. Lambung Mangkurat, Banjarnaru. [Indonesian]

Amirta R, Yuliansyah, Angi EM, Ananto BR, Setyono B, Haqiqi MT, Septiana HA, Lodong M, Oktavianto RN. 2016. Plant diversity and energy potency of community forest in East Kalimantan, Indonesia: Searching for fast growing wood species for energy production. Nusantara Biosci 8 (1): 22-30. DOI: 10.13057/nusbiosci/n080106 [Indonesian]

Birdsey R, Pan Y. 2015. Trends in management of the world's forests and impacts on carbon stocks. For Ecol Manag 355: 83-90. DOI: 10.1016/j.foreco.2015.04.031.

Bredu AS, Birigazzi L. 2014. Proceedings of the regional technical workshop on tree volume and biomass allometric equations in West Africa. UN-REDD Programme MRV Report 21, Kumasi, Ghana, Forestry Research Institute of Ghana. Food and Agriculture Organization of the United Nations, Rome, Italy.

Calfapietra C, Barbati A, Perugini L, Ferrari B, Guidolotti G, Quatrini A, Corona P. 2015. Carbon mitigation potential of different forest ecosystems under climate change and various in Italy. Ecosyst. Heal Sustain 1 (8): 1-9. DOI: 10.1890/EHS15-0023.

Chauhan SK, Sharma R, Panwar P, Chander J. 2016a. Short rotation forestry: a path for economic and environmental prosperity. In: Parthiban KT, Seenivasan R (eds). Forestry Technologies - A Complete Value Chain Approach. Vol.1 Scientific Publishers, Jodhpur.

Chauhan SK, Ritu, Chauhan R. 2016b. Carbon Sequestration in Plantations. Agroforestry for Increased Production and Livelihood Security. New Indian Publishing Agency, New Delhi.

Chave J, Réjou MM, Búrquez A, ChidumayoE, Colgan MS, Delitti WBC, Duque A, Eid T, Fearnside PM, Goodman RC, Henry M, Martínez YrízarA, Mugasha WA, Muller Landau HC, Mencuccini M, Nelson BW, Ngomanda A, Nogueira EM, Ortiz ME, Pélissier R, Ploton P, Ryan CM, SaldarRJG, Vieilleden G. 2014. Improved allometric models to estimate the aboveground biomass of tropical trees. Glob Change Biol 20 (10): 3177-3190. DOI: 10.1111/gcb.12629. 
Cuong T, Chinch TTQ, Zhang Y, Xie Y. 2020. Economic performance of forest plantation in Vietnam: Eucalyptus, Acacia mangium, and Manglietia conifera. Forests 11 (284): 1-14. DOI: 10.3390/f11030284

Dinga E. 2014. On a possible predictor of the cyclical position of the economy. Procedia Econ Finance 8: 254-261. DOI: 10.1016/S22125671(14)00088-4.

Ekholm T. 2016. Optimal forest rotation age under eficient climate change mitigation. For Policy Econ. 62: 62-68. DOI: 10.1016/j.forpol.2015.10.007.

Gonzalez-Benecke CA, Samuelson LJ, Martin TA, Cropper Jr WP, Johnsen KH, Stokes TA, Butnor JR, Anderson PH. 2015. Modeling the effects of forest management on in situ and ex situ longleaf pine forest carbon stocks. For Ecol Manag 355: 24-36. DOI: 10.1016/j.foreco.2015.02.029.

Gren IM, Zeleke AA. 2016. Policy design for forest carbon sequestration: A review of the literature. For Policy Econ 70: 128-136. DOI 10.1016/j.forpol.2016.06.008.

Hairiah K, Rahayu S. 2007. Pengukuran Karbon Tersimpan diberbagai Macam Penggunaan Lahan. World Agroforestry Centre. ICRAF Southeast Asia Regional, Bogor. [Indonesian]

Hairiah K, Andree A, Rika RS, Subekti R. 2011. Measurement of carbon stock from land level to landscape 2nd edition. Agroforestry Center, Bogor. [Indonesian]

Irundu D, Beddu MA, Najmawati. 2020. Potential of biomass and carbon stored stands in green open space Polewali City, West Sulawesi. J Forests Communities 12 (1): 49-57.

Juwari, Ruhiyat D, Aipassa MI, Ruslim Y. 2020a. Carbon stocks of Rhizhopora apiculata and Sonneratia alba of mangrove forest in Ngurah Rai Forest Park, Bali Province, Indonesia. J Biodivers Environ Sci 16 (3): 93-105

Juwari, Ruhiyat D, Aipasaa MI. 2020. Growth analysis of Rhizophora Mucronata mangrove in Ngurah Rai Forest Park (Sanur) Bali Province, Indonesia. Energy Environ Res 10 (1): 30-35.

Karyati, Widiati KY, Karmini, Mulyadi R. 2019. Development of allometric relationships for estimate above-ground biomass of trees in the tropical abandoned land. Biodiversitas 20 (12): 3508-3516. DOI 10.13057/biodiv/d201207. [Indonesian]

Kasim AR, Henry M. Danial M, Faiz M, Birigazi L. 2014. Inventory of tree biomass and volume allometric equations in Southeast Asia FRIM, Kepong, Food and Agriculture Organization of the United Nations, Rome, Italy.

Krisnawati H, Kallio M, Kanninen M. 2011. Anthocephalus cadamba Miq. Ecology, Silviculture and Productivity. CIFOR, Bogor

Kristiningrum R, Lahjie A, Masjaya, Yusuf S, Ruslim Y. 2019. Species diversity, stand productivity, aboveground biomass and economic value of mangrove ecosystem in Mentawir Village, East Kalimantan, Indonesia. Biodiversitas 20 (10): 2848-2857. DOI: 10.13057/biodiv/d201010. [Indonesian]

Kumi JA, Kyereh B, Ansong M, Ansate W. 2020. Influence of management practices on stand biomass, carbon stocks and soil nutrient variability of teak plantations in a dry semi-deciduous forest in Ghana. Trees For People 3: 100049. DOI: 10.1016/j.tfp.2020.100049.

Lubis SH, Arifin SH, Samsoedin I. 2013. Analysis of tree carbon stocks in forest landscapes city in DKI Jakarta. J Forest Sos Econ Research, 10 (1): $1-20$.

Lukito M, Rohmatiah A. 2013. Estimated biomass and carbon of teak 5 year (Case of Nusantara Superior Teak Plantation Forest (JUN) Krowe Village, Lembeyan District, Magetan Regency). Agritek J 14 (1): 1-23. DOI: $10.12988 / \mathrm{asb} .2017 .7924$.

Meunpong P. 2012. Nutrient and Carbon Storage in Forest Plantation, Prachuap Khiri Khan province, Thailand. Kasetsart University, Bangkok, Thailand. [Dissertation]. Kasetsart University, Bangkok, Thailand.

Nemeth R, Feher S, Koman S. 2018. Utilization of fast-growing plantation timber as bioenergy in Hungary. 2018 4th International Conference on Environment and Renewable Energy (ICERE 2018). Da Nang, Vietnam, 25-27 February 2018.

Nonini L, Fiala M. 2019. Estimation of carbon storage of forest biomass for voluntary carbon markets: Preliminary results. J For Res 32 (1) 329-338. DOI: 10.1007/s11676-019-01074-w.

Panwar P, Chauhan S, Kaushal R, Das DK, Ajit, Arora G, Chaturvedi OP, Jain AK, Chaturvedi S, Tewari S. 2017. Carbon sequestration potential of poplar-based agroforestry using the $\mathrm{CO}_{2}$ FIX model in the Indo Gangetic Region of India. Trop Ecol 58 (2): 1-9.
Rinnamang S, Sirirueang K, Supavetch S, Meunpong P. 2020. Estimation of aboveground biomass using aerial photogrammetry from unmanned aerial vehicles in teak (Tectona grandis) plantation in Thailand. Biodiversitas 21 (6): 2369-2376. DOI: 10.13057/biodiv/d210605

Riutta T, Malhi Y, Kho LK, Marthews TR, Huasco WH, Khoo M. 2018. Logging disturbance shift net primary productivity and its allocation in Bornean tropical forest. J. Glob Change Biol 24 (7): 2913-2928. DOI: $10.1111 / \mathrm{gcb} .14068$

Ruslianto M, Alviani, Maisuri, Irundu. 2019. Biomass allometric model of Rhizophora Apiculata at Polewali Mandar Regency, West Sulawesi Province. Buletin Eboni 1 (1): 11-19. [Indonesian]

Pandey S, Shukla R, Saket R, Verma D. 2019. Enhancing carbon stocks accumulation through forest protection and regeneration. A review. Intl J Environ 8 (1): 16-21.

Putri AHM, Wulandari C. 2015. Potential carbon absorption in Shorea javanica in Pekon Gunung Kemala Krui, West Lampung. Sylva Lestari 3 (2): 13- 20. DOI: 10.23960/jsl2313-20 [Indonesian]

Polosakan R, Alhamd L, Joeni SR. 2014. Estimated biomass and carbon stored in Pinus merkusii Jungh. \& de Vriese in the pine forest Mt. Bunder, TN. GN Halimun Salak. Biol News 13 (2): 15-120. [Indonesian]

Sandalayuk. D, Soedirman S, Pambudhi F. 2018. Reserves estimating carbon in forest city district village Bongohulawa Gorontalo. IJRTEM 2 (8): 60-63.

Sandalayuk D, Lahjie AM, Simarangkir BDAS, Ruslim Y. 2020. Carbon absorbtion of Anthocephalus macrophyllus and Swietenia macrophylla. King in Gorontalo, Indonesia. J Biodivers Environ Sci 16 (5): $24-30$

Sardjono A, Lahjie AM, Simarangkir BDAS, Kristiningrum R, Ruslim Y. 2017. Carbon sequestration and growth of Anthocephalus cadamba plantation in North Kalimantan, Indonesian. Biodiversitas 18 (4): 1385-1393. DOI: 10.13057/biodiv/d180414. [Indonesian]

Sedjarawan W, Akhbar, Arianingsih I. 2014. Biomassa dan karbon pohon di atas permukaan tanah ditepi jalan taman nasional Lore Lindu. J Warta Rimba 2 (1): 105-115. [Indonesian]

Sharma R, Chauhan SK, Tripathi AM. 2016. Carbon sequestration potential in agroforestry system in India: An analysis for carbon project. Agrofor Syst 90 (4): 631-644. DOI: 10.4172/21577617.1000131.

Setiawan B, Lahjie AM. 2011. Financial analysis of agroforestry systems teak, sungkai, and elephant grass in Samboja Kutai District Kartanegara. Humida Trop For 4 (1):-. [Indonesian]

Setiawan B, Lahjie AM, Yusuf S, Ruslim. 2019. Model of community forest land management production and financial simulation of super teak, solomon teak and sungkai trees in Samboja Kutai Kartanegara East Kalimantan, Indonesia. Energy Environ Res 9 (20): 48-60.

SNI. 2011. Indonesian National Standard Number 7724. Measurement and calculation of carbon stocks - field measurement for forest carbon stock assessment. Standardization Agency, Jakarta. [Indonesian]

Siregar UJ, Narendra BH, Suryana J, Siregar CA, Weston C. 2017. Evaluation on community tree plantations as sustainable source for rural bioenergy in Indonesia. IOP Conf Ser: Earth Environ Sci. International Conference on Biomass: Technology, Application, and Sustainable Development. Bogor, Indonesia, 10-11 October 2016.

Sist P, Nicolas P, Fleury SG. 2003. Sustainable cutting cycle and yields in a lowland mixed dipterocarp forest of Borneo. Ann For Sci 60 (8): 803-814. DOI: $10.1051 /$ forest:2003075.

Sousa VB, Cardoso S, Quilho T, Pereira H. 2011. Growth and ring width variability of teak, Tectona grandis (Verbenaceae) in an unmanaged forest East Timor. Int J Trop Biol 60 (1): 483-494. ISSN-0034-7744.

Susila IWW. 2012. Estimation model of teak stand volume and increment in Nusa Penida, Klungkung Bali. J Plant For Res 9 (3): 165-178.

Tesfaye MA, Bravo F, Ruiz-Peinado R, Pando V, Bravo-Oviedo A. 2016. Impact of changes in land use, species and elevation on soil organic carbon and total nitrogen in Ethiopian Central Highlands. Geoderma 261: 70-79. DOI: 10.1016/j.geoderma.2015.06.022.

Tuheteru FD, Husna. 2011. Growth and biomass Albizia saponaria on local arbuscular mycorrhizae fungi from Southeast Sulawesi. J Sivikultur Tropika 2(3): 143-148.[Indonesian]

Trimanto. 2014. Vegetation analysis and tree biomass estimation of carbon stocks in Seven Montane Forests of Bawean Island Nature Reserve, East Java. Biol News 13 (1): 321-332. [Indonesian]

Uthbah Z, Sudiana E, Yani E. 2017. Biomass analysis and carbon stock at various ages of resin stands Agathis dammara (Lamb.) Rich.) in KPH Banyumas Timur. Scr Biol 4 (2): 119-124. 
DOI: $10.20884 / 1 . s b .2017 .4 .2 .404$

Van Gardingen PR, McLeish MJ, Philips PD, Fadilah D, Tyrie G, Yasman I. 2003. Financial and ecological analysis of management options for logged-over dipterocarp forest in Indonesia Borneo. For Ecol Manag 183 (1-3): 1-29. DOI: 10.1016/S0378-1127(03)00097-5

Warner AJ, Jamroenprucksa M, Puangchit L. 2017. Buttressing impact on diameter estimation in plantation teak (Tectona grandis L.f.) sample trees in northern Thailand. Agric Nat Resour 51 (6): 520-525. DOI: 10.1016/j.anres.2018.01.001

Wei RP, Zhu W. 2019. Adaptability and growth of a fast-growing Neolamarckia cadamba (Robx.) Bosser clone in the south subtropical region of China. Open J Forestry 9, 419-438. DOI: 10.4236/ojf.2019.94024
Winarni B, Lahjie AM, Simarangkir BDAS, Yusuf S, Ruslim Y. 2017. Tengkawang cultivation model in community forest using agroforestry system in West Kalimantan, Indonesia. Biodiversitas 18 (2): 765-772. DOI: 10.13057/biodiv/d180249 [Indonesian]

Yunianti AD, Wahyudi, Siregar, Pari. 2011. Quality of teak clones with different planting distances. J Wood Sci Tech Trop 9 (1): 93-100. [Indonesian]

Zeng W, Fu L, Xu M, Wang X, Chen Z, Yao S. 2018. Developing individual tree-based models estimating aboveground biomass of five key coniferous species in China. J For Res 29 (5): 1251-1261. DOI: $10.1007 / \mathrm{s} 11676-017-0538-9$. 